\title{
Reviewers for Kew Bulletin Volume 73
}

This year we are not publishing a list of reviewers as it would not comply with GDPR regulations that came into effect in May 2018: reviewers have not given their written consent to have their name printed publicly in a journal issue. As of 2019, we will roll out the option for reviewers to link their reviewing activity to their ORCID id, and thereby receive credit for their peer review.

We thank all the reviewers who carried out reviews for Kew Bulletin in 2017 - 2018.

T. M. A. Utteridge Editor-in-Chief, Kew Bulletin Royal Botanic Gardens, Kew

Publisher's Note Springer Nature remains neutral with regard to jurisdictional claims in published maps and institutional affiliations. 